ISSN 1112-9867

http://www.jfas.info

\title{
MERGERS AND ACQUISITIONS'S IMPACT ON FINANCIAL PERFORMANCE: AN EVALUATION WITH PERSPECTIVE OF TIME
}

\author{
V. M. Lakhwani ${ }^{*}$, S. Tiwari $^{2}$, and S. Jauhari ${ }^{3}$ \\ ${ }^{1}$ Faculty Member, ICFAI Business School (IBS) Ahmedabad \\ ${ }^{2}$ Corporate Trainer and Consultant, Catchup Consultant Pvt. Ltd., Bhopal \\ ${ }^{3}$ HOD - Management, AISECT Uinversity, Bhopal
}

Published online: 17 October 2017

\begin{abstract}
Mergers and Acquisitions (M\&A) is the most prefered technique of the corpoates from diversed areas across the globe for achieiving inorganic growth. In Indian context, M\&A has a graceful history from pre liberalization to post librelization period wherein the companies have used this process in different scenarios to accomplish various objectives. Though this method have enormous benefits but at the same time are firms are able to convert these qualitative aspects into quantitative form and if yes than do they see an immediate impact or it takes considerable time to reflect same in their financial performance. The present research work with the help of Du Pont Return on Assets (ROA) framework assess the success of M\&A in the long run by taking a sample of 24 companies that have acquired companies in financial year 2005- 2006 .
\end{abstract}

Keywords: mergers and acquisitions; du pont analysis; long run; financial performance; return on assets.

Author Correspondence, e-mail: cwrslakhwanivm@gmail.com

doi: http://dx.doi.org/10.4314/jfas.v9i5s.67 


\section{INTRODUCTION}

In today's highly dynamic and fierce competitive business world, corportes are force to develop and rethink their strategies not only to secure but also maintain their business growth. Internal expansion and external expansion are the two different ways that helps the firm to fuel their growth engine. With respect to former, business enterprises by evaluating their internal strengths and weakness can decide the course of action for expansion which can be in either form - coming up with new segments, developing new products in same segment or targeting new markets all together. In case of latter, companies always look into the opportunities available in the outer world for development. The different structures through which external expansion can be done are - Strategic Alliance, Joint Ventures, or Mergers and Acquisitions (M\&A).

From all three M\&A is the most common and well received route opted globally by business units for external expansion. M\&A is a three stages process - The first stage starts before M\&A which comprises of selecting a target, due diligence, deal finalization. Second phase is during M\&A which looks into seeking approval from shareholders and other regulatory authorities third phase starts after M\&A which takes care of integration process. Once the entire process gets over an analysis has to be done that whether the firm was able to build upon the synegries or not with an objective of which M\&A was done. If yes, than the benefits so derived from such synergies will have an immediate impact or will it take substaintial time to reflect same in their financial performance.

The present study has been undertaken to seek the answers of these questions by studying the financial performance before and after merger of the companies by calcuating the three ratios return on assets, net profit margin and asset turnover ratio as per Du Pont framework.

\subsection{Objective of the Study}

As stated in previous paragraphs, the present study has been conducted with an objective to evaluate whether post merger the financial performance of the companies improve in the long run or not. Keeping in view the same the following hypotheis has been formulated:$\mathrm{H}_{0}=$ There is no significant effect on Return on Assets (ROA) before and after M\&A. $\mathrm{H}_{1}=$ There is significant effect on Return on Assets (ROA) before and after M\&A. 
$\mathrm{H}_{0}=$ There is no significant effect on Net Profit Margin (NPM) before and after M\&A.

$\mathrm{H}_{1}=$ There is significant effect on Net Profit Margin (NPM) before and after M\&A.

$\mathrm{H}_{0}=$ There is no significant effect on Asset Turnover Ratio (ATR) before and after M\&A.

$\mathrm{H}_{1}=$ There is significant effect on Asset Turnover Ratio (ATR) before and after M\&A.

\subsection{Literature Review}

[1] analyzed the impact of M\&A in Malaysian banking sector by studying the 10 banking groups that came into existence by merging 52 banking institution. To have a check on profitability improvement after merger pre and post return on assets and return on equity ratios were calculated and compared. The end result showed a positive trend subsequent the merger. They also discovered that M\&A was much needed in order to overcome financial crisis and international agreements.

[2] applied event study as well as accounting ratios method to the 12 companies selected from the time frame of 1999 - 2005 acquisitions deals in order to assess the success or failure of M\&A. Based on the event study results it was deduced that shareholders of the target companies benefited immediately because of high premium paid by the acquirer for buying the company and acquirer companies' shareholders reap abnormal returns within the time frame of two years. As per accounting ratios, ROCE and RONW were improved. However only half of the companies were able to take advantage of cost reduction and made better use of fixed assets.

[3] conducted their study by selecting 22 mergers and 52 acquisitions as a sample from M\&A deals in 2003. They compared the financial results by working out liquidity, operating, overall efficiency, equity shareholders' return ratios for three years each - pre deal and post deal. The end results showed that in maximum cases of mergers as well as acquisitions the companies were able to generate synergies by gauging the better financial performance in post-merging and acquisition scenario.

[4] undertook study of the firms that did acquisition from 1999- 2002. He finalized 30 companies as a sample and assessed their results by computing and comparing profitability, operating and leverage ratios for three years pre and three years post-acquisition. The outcome was that companies not registered significance improvement in financial performance after merger. 
[5] inferred from his study that mergers have proven to be beneficial for the Indian corporates performance in the long run. He conducted his study by taking sample of 87 firms from the merger deals of January 1996 to March 2002 and determined pretax operating cash flows for three years before and after merger.

[6] evaluated the financial performance of Indian Pharmaceutical sector by taking top 3 players as a sample. They used Dupont Analysis and calculated ROI and ROE accordingly for the period of ten years (2003-2012). They found that pharma companies are more focused on absolute measures rather than relative which will may not present a true and fair picture every time. Hence relative size of the firms should also be taken into consideration while computing ratios.

[7] researched to find out the firm level determinants that paly decisive role in deciding for the business enterprises as to whether go for acquisition or not. With sample of 360 companies from the time frame 2004-2010 and restricting to three sectors - FMCG, Automobile and Pharmaceutical it was found that business group affiliation and earning volatility are the two crucial elements for the corporates to decide to opt for M\&A or not.

[8] conducted their study to assess the effect on efficiency, growth and profitability on Nigerian Banks in post M\&A scenario. They analyzed the key financial ratios of the 10 banks selected as a sample. The results of their study were that M\&A has positive impact on bank profitability and operating efficiency but also at the same time leads to post consolidation crisis in Nigerian banking sector.

[9] researched on the Indian corporates acquiring companies in foreign by restricting samples to only those acquisitions that were successful and acquirer had took over majority stake in the target. For ascertaining the results, operating cash flow ratios and asset turnover ratios were computed for three pre as well as post-merger. The conclusion of the study was cross border acquisition does not lead to higher performance in long term and in case where targets are relatively big in size as compare to acquiring firm the results are still worse.

[10] conducted their study specific to Indian manufacturing sectors by selecting the deals during 2003-2004 to 2006-2007. They computed liquidity, profitability and solvency ratios and compared the effect with pre and post-merger taking the time frame of three years for each. Their research findings were that M\&A impact were reflected in the immediate years 
categorically in event and the first year after M\&A.

[11] investigated as to whether merger should be allowed or not as per the conditions laid down Fiji's M\&A legislation by taking two case studies. The first case was about conglomerate merger where the firms were involved into different type of beverage activity alcoholic and soft drink and had no impact on the individual market share. In second case, the firm was "failing unit" and need to be salvaged. Along with regulatory requirement, financial position of the firm was assessed by computing profitability, rate of return, liquidity, efficiency and leverage ratios. Therefore, merger should be allowed as it was in public interest. They concluded that in both the cases M\&A applications were cleared.

[12] found that M\&A improves the profitability as well as enhance the speed of innovation. They conducted their study specific to Indian pharmaceutical sector by taking sample of four companies who done acquisition overseas. For arriving at result they took financial and patent fillings data for eight years and measured profitability with respect to gross profit and operating margins.

[13] studied the long term performance of acquiring firm by comparing the operating cash flows ratios in Du Pont framework for five years prior and post-merger. They finalized the sample of 383 mergers and acquisition that took place from January 2003 to December 2008 . The end result depicts that the financial performance of the acquirer has enhanced after merger.

\section{RESULTS AND DISCUSSION}

\subsection{Impact on Return on Asset (ROA) Ratio}

Looking at the descriptive statistics (Table 3), the mean of pre and post-merger ROA, depicts that there is improvement in the performance of 18 companies after merger. However the standard deviation presents different picture altogether. From 18 firms, the standard deviation of 10 firms has been on higher side and the rest 8 registered lower deviations. In case of former, although there return has increased but at same time there was fluctuation in each year earning with respect to increase in assets after merger period whereas latter represent along with boost in return, there is consistency in revenues in tandem to greater size of assets subsequent to merger. Further to signify more, paired t test was applied (Table 4) and it was 
found that ROA of only six companies namely Dabur India Ltd, EIH Associated Hotels Ltd., HIL Ltd., Lakshmi Machine Works Ltd., Mphasis Ltd. and VIP Industries Ltd. has shown significant effect in terms of improvement whereas that of Forbes \& Co. Ltd there is a significant effect in ratio, but surprisingly the average values has gone down.

\subsection{Effect on Net Profit Margin (NPM) Ratio}

On comparing the pre and post-merger mean (Table 3), it is clearly observed that post-merger NPM of 15 firms has increased. While studying the variation, the results found were different from averages. The level of differences was high in 10 firms and low in 5 firms. This implies that with better margins majority of companies experienced swing in profitability with augmented sales and very few were able to lessen the variation in the profits with higher sales after unification. Dabur India Ltd., EIH Associated Hotels Ltd., HIL Ltd., Lakshmi Machine Works Ltd. and Larsen and Tubro Ltd. are the five acquirers whose NPM has significantly enhanced (Table 5).

\subsection{Influence of Merger on Asset Turnover Ratio (ATR) Ratio}

While comparing the mean and standard deviation of ATR in before and after merger scenario (Table 3) it was found that ATR of eleven companies 11 has been significantly enhanced. The outcome of differential was opposite to earlier observations in which 8 firms were found with lesser and 3 firms with high variance. It means that major chunk of firms earlier were not able to utilize the asset properly due to sales vary but with the added sales and increased assets it has been used efficiently and also the deviation in sales has gone down. Akar Tools Ltd., EIH Associated Hotels Ltd., HIL Ltd., JSW Ltd., Thermax Ltd., Universal Cables Ltd., and VIP Industries Ltd., are the seven firms whose ATR has become better, on the other side ATR of Forbes \& Co. Ltd., Punjab Chemicals \& Crop Protection Ltd., RSWM Ltd. and Tata Global Beverages Ltd. have dropped significantly after merger (Table 6).

\subsection{Forecasted Values using ARIMA Model}

After studying the pre and post M\&A results, ARIMA model was applied on all three ratios of all sample companies taken for the study. The data set used was for nine years for each parameter after merger and the values were forecasted for two years i.e. (2016 and 2017). The observation from the results were the forecasted value of ten firms for all three ratios were going up, for six firms the values for all three ratios were falling. In rest eight firms, mix 
results were found. ATR was the first with high values followed by ROA and NPM respectively.

\subsection{DISCUSSION}

In post-merger scenario, the profitability in terms of ROA has notably improved for one company, NPM for one company and both (ROA and NPM) for two companies respectively. Improvement in ROA clearly indicates companies have been benefited from M\&A activity and able to generate higher returns and become more profitable. Higher NPM shows that firms took the advantage becoming bigger in size that equipped more bargaining power and achieving economies of scale lead to fetching better profit margins. Firms that have performed well on both parameters reveals that the merger has significant impact on overall profitability of the acquiring firm which can attribute to cost efficiencies, better sales mix and good market share.

With respect to efficiency, ATR of four acquirers has become better after merger which shows that these firms have effectively utilized the assets as compare to before merger. The probable reason could be with increased customer base the combined entity have generated more sales. The ROA and ATR has gone up for a firm after merger which shows that company along with better returns has also put the assets to productive use. This has happened because of cost measures have been implemented along with introduction of new operating matrices.

Finally, two companies have registered significant improvement in profitability and efficiency by performing better on all three parameters highlighting that proper integration process has been followed which has been well thought off before merger. As a result, the company has been able to achieve better results with enhanced financial performance. This also validates the Du Pont ROA framework which suggests that all three ratios are interrelated with each other.

\section{EXPERIMENTAL}

\subsection{Data Collection and Methodology Applied}

The current study is carried out solely on secondary database. In-depth information with repect to the M\&A deals of F.Y. 2005-2006 and financial data about sales, net profit and total assets for computing ratios has been collected from Prowess - Centre For Monitoring Indian 
Economics (CMIE) Database. Additionally annual reports and websites of the companies and stock excahnges has been referred to validate the deals. With a view of having comprehensible results, M\&A deals between the companies having holding subsidiary relationship from inception has been excluded. Out of 168 deals, only 39 deals comprising of 33 companies were selected for second stage. Further companies that belonged to banking, financial services sectors and about whom financial data was not available were excluded. As a result the sample of 24 companies constituting $26 \mathrm{M} \& \mathrm{~A}$ pacts was finalized.

Table 1. Companies finalized for the study

\begin{tabular}{|c|c|c|c|c|}
\hline S.No & $\begin{array}{l}\text { Name of } \\
\text { Acquirer }\end{array}$ & $\begin{array}{l}\text { Main Sector of } \\
\text { Acquirer }\end{array}$ & $\begin{array}{l}\text { Name of } \\
\text { Company(ies) } \\
\text { Targeted \& } \\
\text { Merged } \\
\end{array}$ & $\begin{array}{l}\text { Main Sector of } \\
\text { Target }\end{array}$ \\
\hline \multirow{3}{*}{1} & \multirow{3}{*}{ Dabur India Ltd. } & \multirow{3}{*}{ Consumer oods } & $\begin{array}{l}\text { Balsara Home } \\
\text { Products Ltd. }\end{array}$ & \multirow{2}{*}{$\begin{array}{l}\text { Consumer } \\
\text { Goods }\end{array}$} \\
\hline & & & $\begin{array}{l}\text { Balsara Hygiene } \\
\text { Products Ltd. }\end{array}$ & \\
\hline & & & $\begin{array}{l}\text { Besta Cosmetics } \\
\text { Ltd. }\end{array}$ & Misc. Services \\
\hline 2 & Akar Tools Ltd. & Machinery & $\begin{array}{l}\text { Ajanta Auto Inds. } \\
\text { Pvt. Ltd. }\end{array}$ & $\begin{array}{l}\text { Transport } \\
\text { Equipment }\end{array}$ \\
\hline 3 & $\begin{array}{l}\text { Punjab } \\
\text { Chemicals \& } \\
\text { Crop Protection } \\
\text { Ltd. }\end{array}$ & $\begin{array}{l}\text { Chemical and } \\
\text { Chemical } \\
\text { Products }\end{array}$ & $\begin{array}{l}\text { Alpha Drug India } \\
\text { Ltd. }\end{array}$ & $\begin{array}{l}\text { Chemical and } \\
\text { Chemical } \\
\text { Products }\end{array}$ \\
\hline 4 & $\begin{array}{l}\text { V I P Industries } \\
\text { Ltd. }\end{array}$ & $\begin{array}{l}\text { Chemical and } \\
\text { Chemical } \\
\text { Products } \\
\end{array}$ & $\begin{array}{l}\text { Aristocrat Luggage } \\
\text { Ltd. }\end{array}$ & $\begin{array}{l}\text { Chemical and } \\
\text { Chemical } \\
\text { Products }\end{array}$ \\
\hline 5 & $\begin{array}{l}\text { Kesoram } \\
\text { Industries Ltd. }\end{array}$ & $\begin{array}{l}\text { Transport } \\
\text { Equipment }\end{array}$ & $\begin{array}{l}\text { Assam Cotton } \\
\text { Mills Ltd. }\end{array}$ & Textiles \\
\hline 6 & $\begin{array}{l}\text { Larsen \& Toubro } \\
\text { Ltd. }\end{array}$ & $\begin{array}{l}\text { Industrial and } \\
\text { Infrastructural } \\
\text { Construction }\end{array}$ & $\begin{array}{l}\text { Datar Switchgear } \\
\text { Ltd. }\end{array}$ & Machinery \\
\hline 7 & $\begin{array}{l}\text { Videocon } \\
\text { Industries Ltd. }\end{array}$ & $\begin{array}{l}\text { Consumer } \\
\text { Goods }\end{array}$ & $\begin{array}{l}\text { E K L Appliances } \\
\text { Ltd. }\end{array}$ & $\begin{array}{l}\text { Consumer } \\
\text { Goods }\end{array}$ \\
\hline 8 & J S W Steel Ltd. & $\begin{array}{l}\text { Metals and } \\
\text { Metals Products }\end{array}$ & $\begin{array}{l}\text { Euro Coke \& } \\
\text { Energy Pvt. Ltd. }\end{array}$ & Mining \\
\hline 9 & $\begin{array}{l}\text { Forbes \& Co. } \\
\text { Ltd. }\end{array}$ & Machinery & $\begin{array}{l}\text { F A L Industries } \\
\text { Ltd. }\end{array}$ & $\begin{array}{l}\text { Consumer } \\
\text { Goods }\end{array}$ \\
\hline 10 & Kamat Hotels & Hotels and & Himco (India) Ltd. & Hotels and \\
\hline
\end{tabular}




\begin{tabular}{|c|c|c|c|c|}
\hline & (India) Ltd. & Tourism & & Tourism \\
\hline 11 & $\begin{array}{l}\text { E I H Associated } \\
\text { Hotels Ltd. }\end{array}$ & $\begin{array}{l}\text { Hotels and } \\
\text { Tourism }\end{array}$ & $\begin{array}{l}\text { Indus Hotel Corpn. } \\
\text { Ltd. }\end{array}$ & $\begin{array}{l}\text { Hotels and } \\
\text { Tourism }\end{array}$ \\
\hline 12 & $\begin{array}{l}\text { Lakshmi } \\
\text { Machine Works } \\
\text { Ltd. }\end{array}$ & Machinery & $\begin{array}{l}\text { Jeetstex } \\
\text { Engineering Ltd. }\end{array}$ & Machinery \\
\hline 13 & Mphasis Ltd. & $\begin{array}{l}\text { Information } \\
\text { Technology }\end{array}$ & $\begin{array}{l}\text { Kshema } \\
\text { Technologies Ltd. }\end{array}$ & $\begin{array}{l}\text { Information } \\
\text { Technology }\end{array}$ \\
\hline 14 & H I L Ltd. & $\begin{array}{l}\text { Construction } \\
\text { Materials }\end{array}$ & $\begin{array}{l}\text { Malabar Building } \\
\text { Products Ltd. }\end{array}$ & $\begin{array}{l}\text { Construction } \\
\text { Materials }\end{array}$ \\
\hline 15 & $\begin{array}{l}\text { Dhampur Sugar } \\
\text { Mills Ltd. }\end{array}$ & $\begin{array}{l}\text { Food and Agro } \\
\text { Based Products }\end{array}$ & $\begin{array}{l}\text { Mansurpur Sugar } \\
\text { Mills Ltd. }\end{array}$ & $\begin{array}{l}\text { Food and Agro } \\
\text { Based Products }\end{array}$ \\
\hline 16 & R S W M Ltd. & Textiles & $\begin{array}{l}\text { Mordi Textiles \& } \\
\text { Processors Ltd. }\end{array}$ & Textiles \\
\hline 17 & $\begin{array}{l}\text { Universal Cables } \\
\text { Ltd. }\end{array}$ & Machinery & $\begin{array}{l}\text { Optic Fibre Goa } \\
\text { Ltd. }\end{array}$ & $\begin{array}{l}\text { Miscellaneous } \\
\text { Manufacturing }\end{array}$ \\
\hline 18 & Goa Carbon Ltd. & $\begin{array}{l}\text { Chemical and } \\
\text { Chemical } \\
\text { Products }\end{array}$ & $\begin{array}{l}\text { Paradeep Carbons } \\
\text { Ltd. }\end{array}$ & $\begin{array}{l}\text { Chemical and } \\
\text { Chemical } \\
\text { Products }\end{array}$ \\
\hline 19 & Wanbury Ltd. & $\begin{array}{l}\text { Chemical and } \\
\text { Chemical } \\
\text { Products }\end{array}$ & $\begin{array}{l}\text { Pharmaceutical } \\
\text { Products Of India } \\
\text { Ltd. }\end{array}$ & $\begin{array}{l}\text { Wholesale and } \\
\text { Retail Trading }\end{array}$ \\
\hline 20 & H M T Ltd. & Machinery & Praga Tools Ltd. & Machinery \\
\hline 21 & $\begin{array}{l}\text { Century } \\
\text { Plyboards (India) } \\
\text { Ltd. }\end{array}$ & $\begin{array}{l}\text { Construction } \\
\text { Materials }\end{array}$ & $\begin{array}{l}\text { Shyam Century } \\
\text { Ferrous Ltd. }\end{array}$ & $\begin{array}{l}\text { Metals and } \\
\text { Metals Products }\end{array}$ \\
\hline 22 & $\begin{array}{l}\text { Hindustan } \\
\text { Unilever Ltd. }\end{array}$ & $\begin{array}{l}\text { Consumer } \\
\text { Goods }\end{array}$ & $\begin{array}{l}\text { T O C Disinfectants } \\
\text { Ltd. }\end{array}$ & $\begin{array}{l}\text { Consumer } \\
\text { Goods }\end{array}$ \\
\hline 23 & $\begin{array}{l}\text { Tata Global } \\
\text { Beverages Ltd. }\end{array}$ & $\begin{array}{l}\text { Food and Agro } \\
\text { Based Products }\end{array}$ & Tata Tetley Ltd. & $\begin{array}{l}\text { Food and Agro } \\
\text { Based Products }\end{array}$ \\
\hline 24 & Thermax Ltd. & Machinery & $\begin{array}{l}\text { Thermax Babcock } \\
\text { \& Wilcox Ltd. }\end{array}$ & Machinery \\
\hline
\end{tabular}


Table 2. Sector wise classification of acquiring companies

\begin{tabular}{|c|l|c|c|}
\hline S. No & Sectors & $\begin{array}{c}\text { No. of M\&A } \\
\text { Deals }\end{array}$ & $\begin{array}{c}\text { No. of } \\
\text { Companies }\end{array}$ \\
\hline 1 & Chemical and Chemical Products & 4 & 4 \\
\hline 2 & Construction Materials & 2 & 2 \\
\hline 3 & Consumer Goods & 5 & 3 \\
\hline 4 & Food and Agro Based Products & 2 & 2 \\
\hline 5 & Hotels and Tourism & 2 & 2 \\
\hline 6 & $\begin{array}{l}\text { Industrial and Infrastructural } \\
\text { Construction }\end{array}$ & 1 & 1 \\
\hline 7 & Information Technology & 1 & 1 \\
\hline 8 & Machinery & 6 & 6 \\
\hline 9 & Metals and Metals Products & 1 & 1 \\
\hline 10 & Textiles & 1 & 1 \\
\hline 11 & Transport Equipment & 26 & 24 \\
\hline & Total & & \\
\hline
\end{tabular}

Total data was collected for fifteen years, out of six years were before and nine years after the merger. For comparing pre and post-merger performance six years data for each was used and forecasting technique was applied to total nine years subsequent to merger. The time frame of six years were fixed due to availability pre merger data in Prowess database for aforesaid duration only.

Afterwards values for all three ratios were calculated for both time frame- prior and post-merger and analysis was done with reference to mean, standard deviation and coefficient of variation to check the impact of M\&A on the firms. Additionally paired t test were applied at $5 \%$ to check the significant effect. At last Autoregressive Integrated Moving Average (ARIMA) technique was deployed for forecasting the values of all three ratios for the companies that have remarkable effect of M\&A in either of the direction.

\subsection{Du Pont Return on Assets (ROA) Framework}

In 1920s, Du Pont took over General Motors and F. Donaldson Brown who was with the company since 1909 as an explosive salesman and later on promoted to company's finance section was designated as a treasurer of General Motors. He was given the task of cleaning up the chiaotic finance of ailing auto manufacturing company. While working on same, he discovered that multiplication of Net Profit Margin (NPM) with Asset Turnover Ratio (ATR) leads to Return on Assets (ROA). Since then, this model gained popularity as Du Pont 
Analysis.

Return on Assets (ROA) shows profit being earned in relation to assets being deployed into the business in percentage term. Net Profit Margin (NPM) highlights the net income earned by the company with respect to total sales made during a particular time frame. Asset Turnover Ratio (ATR) evince the firm's efficiency in utilizing the assets to generate sales.

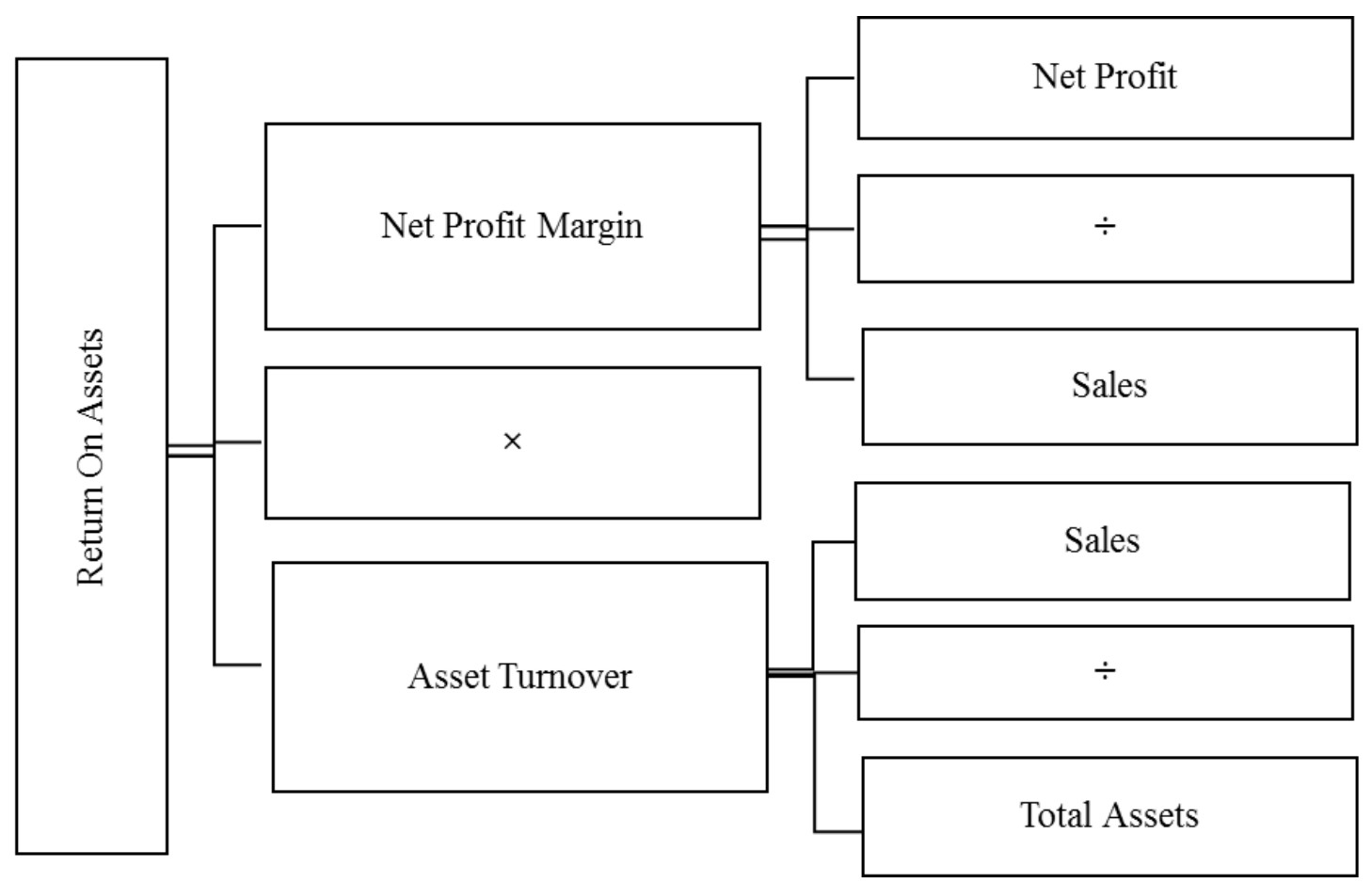

Fig.1. Du Pont ROA framework

\section{CONCLUSION}

In spite of the fact that across the globe M\&A has become a prominent route for attaining inorganic growth for the corporates still they should choose a target for acquiring or merging after carefully analyzing the cost and benefits associated with the deal. A proper integration plan should be designed well in advance to facilitate merger. The current study carried out to measure the financial performance of M\&A in long term with the help of Du Pont ROA Analysis and it is concluded that M\&A is a long term pay off strategy and firms are able to make it long way provided that target selection was made wisely with a well thought plan. It also infers that the results are more specific to the companies rather than a particular sector.

Even from the forecasted value obtained by applying ARIMA model, it was found that M\&A 
is benefited in long term but it entirely dependent on the company who choose this path and the way take it forward. The findings confirmed with earlier results that not the sector but the companies are one who got advantage of M\&A.

\section{REFERENCES}

[1] Shanmugam B, Nair M. Mergers and acquisitions of banks in Malaysia. Managerial Finance, 2003, 30(4):1-18

[2] Chari L. Inorganic growth strategies: An empirical analysis of who benefits from them? 2006

[3] Kumar S, Bansal L K. The impact of mergers and acquisitions on corporate performance in India.Management Decision, 2008, 46(10):1531-1543

[4] Kumar R. Post-merger corporate performance an Indian perspective. Management Research News, 2009, 32(2):145-157

[5] Ramakrishnan, K. Mergers in Indian Industry: Performance and impacting factors. Business Strategy Series, 2010, 11(4):261-268

[6] Sheela C S, Karthikeyan K. Financial performance of pharmaceutical industry in India using DuPont analysis. European Journal of Business and Management, 2012, 4(14):84-91

[7] Agnihotri A. Determinants of acquisitions: An Indian perspective. Management Research Review, 2013, 36(9):882-898

[8] Akinbuli S F, Kelikume I. The effects of mergers and acquisition on corporate growth and profitability: evidence from Nigeria. Global Journal of Business Research, 2013, 7(1):43-58

[9] Kohli R. Analyzing the long run financial performance of cross border acquisitions of Indian acquiring companies and determinants there off. Working Paper, 2013, 37-42

[10] Leepsa N M, Mishra C S. Do mergers \& acquisitions pay off immediately? Evidence from mergers and acquisitions in India. South Asian Journal of Management, 2013, 20(3):39-57

[11] Maharaj B, Reddy M. To clear or not: Examination of mergers and acquisitions cases from small economies. International Journal of Economics and Finance, 2013, 5(2):125-140

[12] Panda T K, Sriram S. Competitive advantage through mergers and acquisitions for Indian pharmaceutical companies. In Proceedings of an International Conference on Business 
Management and International Systems Institute of Management Technology, 2013, pp. $247-253$

[13] Rani N, Yadav S S, and Jain P K. Post M\&A operating performance of Indian acquiring firms: A Du Pont analysis. International Journal of Economics and Finance, 2013, 5(8):65-75

\section{How to cite this article:}

Lakhwani V M, Tiwari S, and Jauhari S. Mergers and acquisitions's impact on financial performance: An evaluation with perspective of time. J. Fundam. Appl. Sci., 2017, 9(5S), 945-957. 


\begin{tabular}{|c|c|c|c|c|c|c|c|c|c|c|c|}
\hline \multirow[b]{2}{*}{$\begin{array}{l}\text { Company } \\
\text { Name }\end{array}$} & \multicolumn{4}{|c|}{ Return on Assets } & \multicolumn{4}{|c|}{ Net Profit Margin } & \multicolumn{3}{|c|}{ Asset Turnover Ratio } \\
\hline & $\begin{array}{c}\text { Pre-Merger } \\
\text { Mean }\end{array}$ & $\begin{array}{c}\text { Post-Merger } \\
\text { Mean }\end{array}$ & $\begin{array}{c}\text { Pre-Merger } \\
\text { Std. } \\
\text { Deviation }\end{array}$ & \begin{tabular}{|c|} 
Post-Merger \\
Std. \\
Deviation \\
\end{tabular} & $\begin{array}{c}\text { Pre-Merger } \\
\text { Mean }\end{array}$ & $\begin{array}{c}\text { Post-Merger } \\
\text { Mean }\end{array}$ & $\begin{array}{c}\text { Pre-Merger } \\
\text { Std. } \\
\text { Deviation }\end{array}$ & $\begin{array}{c}\text { Post-Merger } \\
\text { Std. } \\
\text { Deviation } \\
\end{array}$ & $\begin{array}{c}\text { Pre-Merger } \\
\text { Mean }\end{array}$ & $\begin{array}{c}\text { Post-Merger } \\
\text { Mean }\end{array}$ & $\begin{array}{c}\text { Pre-Merg } \\
\text { Std. } \\
\text { Deviatio }\end{array}$ \\
\hline $\begin{array}{l}\text { Akar } \\
\text { Tools Ltd. }\end{array}$ & 2.8850 & 2.3717 & 1.2341 & 1.2368 & 3.1667 & 1.9300 & 2.0583 & 1.0010 & 0.9867 & 1.2217 & 0.1770 \\
\hline $\begin{array}{l}\text { Century } \\
\text { Plyboards } \\
\text { (India) } \\
\text { Ltd. }\end{array}$ & 6.2317 & 8.9383 & 1.8522 & 4.1397 & 3.9150 & 6.0233 & 1.3524 & 2.9891 & 1.6200 & 1.5200 & 0.144 \\
\hline $\begin{array}{l}\text { Dabur } \\
\text { India Ltd. }\end{array}$ & 13.3850 & 23.6383 & 4.8320 & 5.4413 & 7.8117 & 14.4917 & 2.1424 & 1.1888 & 1.6850 & 1.6183 & 0.2230 \\
\hline $\begin{array}{l}\text { Dhampur } \\
\text { Sugar } \\
\text { Mills Ltd. }\end{array}$ & -1.3783 & 0.2517 & 6.0592 & 2.4050 & -2.5333 & -0.0783 & 7.2723 & 4.9767 & 0.8550 & 0.7600 & 0.2094 \\
\hline $\begin{array}{l}\text { E I H } \\
\text { Associated } \\
\text { Hotels } \\
\text { Ltd. }\end{array}$ & -2.5900 & 2.7183 & 1.4567 & 0.8152 & -11.1700 & 6.7933 & 6.4829 & 1.8063 & 0.2483 & 0.3967 & 0.0519 \\
\hline $\begin{array}{l}\text { Forbes \& } \\
\text { Co. Ltd. }\end{array}$ & 3.5433 & -1.9350 & 2.1017 & 4.5386 & 4.4083 & -4.5100 & 2.3834 & 9.8123 & 0.7917 & 0.5517 & 0.0462 \\
\hline $\begin{array}{l}\text { Goa } \\
\text { Carbon } \\
\text { Ltd. } \\
\end{array}$ & 3.1867 & 3.2833 & 2.75168 & 2.22963 & 3.5983 & 2.8400 & 3.1814 & 2.1924 & 0.9783 & 1.2250 & 0.2564 \\
\hline H I L Ltd. & -0.7750 & 9.1300 & 2.4873 & 5.2622 & -1.0867 & 6.1100 & 2.4147 & 3.3152 & 1.0267 & 1.4733 & 0.1988 \\
\hline $\begin{array}{lll}\mathrm{H} \quad \mathrm{M} & \mathrm{T} \\
\text { Ltd. } & \end{array}$ & -4.7533 & -3.0483 & 11.8452 & 3.0048 & -8.2983 & -26.8017 & 17.9903 & 25.4842 & 0.3083 & 0.1183 & 0.2154 \\
\hline $\begin{array}{l}\text { Hindustan } \\
\text { Unilever } \\
\text { Ltd. } \\
\end{array}$ & 21.7733 & 25.1717 & 3.1126 & 2.8356 & 13.0850 & 12.1800 & 2.7569 & 1.1133 & 1.7000 & 2.0767 & 0.2987 \\
\hline \begin{tabular}{lcc|} 
J & S & W \\
Steel Ltd.
\end{tabular} & 1.2833 & 5.7150 & 5.8224 & 3.0963 & -3.8717 & 8.9767 & 15.7898 & 4.5710 & 0.3667 & 0.6250 & 0.2472 \\
\hline $\begin{array}{l}\text { Kamat } \\
\text { Hotels } \\
\text { (India) } \\
\text { Ltd. } \\
\end{array}$ & लC: & $\begin{array}{c}1.9667 \\
\text { Journal of Fundament } \\
\text { International License. }\end{array}$ & $\begin{array}{c}1.0641 \\
\text { l1 and Applied Scienc } \\
\text { Libraries Resource D }\end{array}$ & $\begin{array}{c}2.5083 \\
\text { s is licensed under a } \mathrm{C} \\
\text { rectory. We are listed }\end{array}$ & $\begin{array}{c}4.1467 \\
\text { eative Commons Attr } \\
\text { ider Research Associ } \\
\end{array}$ & $\begin{array}{c}7.4200 \\
\text { bution-NonCommercia } \\
\text { tions category. }\end{array}$ & $4_{4.0}^{3.7199}$ & 8.5665 & 0.2550 & 0.2133 & 0.0288 \\
\hline $\begin{array}{l}\text { Kesoram } \\
\text { Industries }\end{array}$ & 3.3233 & 5.0700 & 1.3169 & 7.9436 & 2.7683 & 4.21830 & 0.8410 & 7.3959 & 1.1867 & 0.9950 & 0.2125 \\
\hline
\end{tabular}


Table 3: Paired Sample Statistics Results for all Ratios of Acquiring Firms

Table 4: Paired Sample Test Results for Return on Asset Ratio of Acquiring Firms

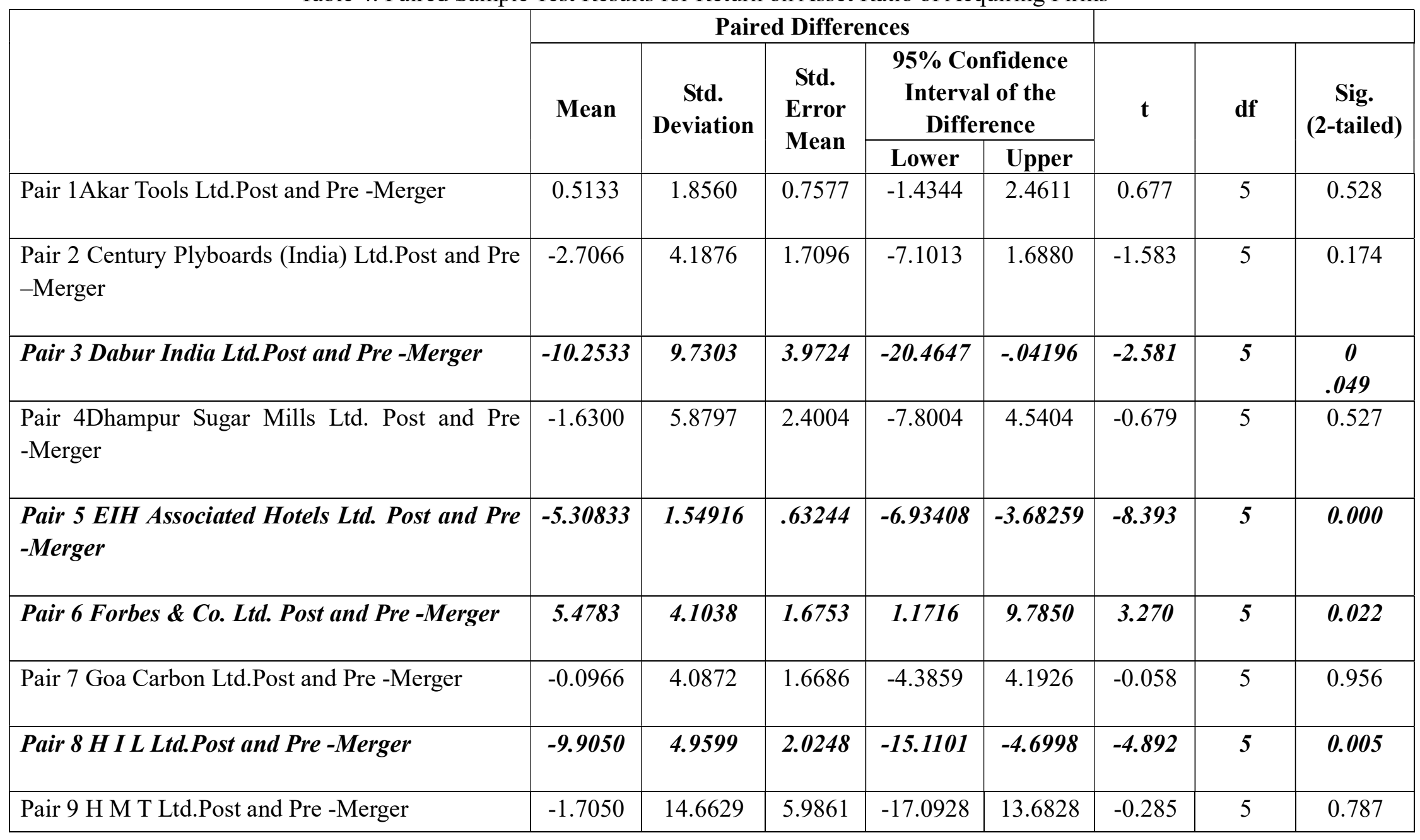




\begin{tabular}{|c|c|c|c|c|c|c|c|c|}
\hline $\begin{array}{l}\text { Pair } 10 \text { Hindustan Unilever Ltd. Post and Pre } \\
\text {-Merger }\end{array}$ & -3.3983 & 3.5258 & 1.4394 & -7.0985 & 0.3018 & -2.361 & 5 & 0.065 \\
\hline Pair 11J S W Steel Ltd. Post and Pre -Merger & -4.4316 & 7.2799 & 2.9720 & -12.0714 & 3.2081 & -1.491 & 5 & 0.196 \\
\hline $\begin{array}{l}\text { Pair } 12 \text { Kamat Hotels (India)Ltd. Post and Pre } \\
\text {-Merger }\end{array}$ & -0.8233 & 1.9907 & 0.8127 & -2.9124 & 1.2657 & -1.013 & 5 & 0.358 \\
\hline $\begin{array}{l}\text { Pair } 13 \text { Kesoram Industries Ltd. Post and Pre } \\
\text {-Merger }\end{array}$ & -1.7466 & 8.4804 & 3.4621 & -10.6463 & 7.1530 & -0.505 & 5 & 0.635 \\
\hline $\begin{array}{l}\text { Pair } 14 \text { Lakshmi Machine Works Ltd. Post and } \\
\text { Pre-Merger }\end{array}$ & -4.4466 & 3.7100 & 1.5146 & -8.3400 & -0.5532 & -2.936 & 5 & 0.032 \\
\hline $\begin{array}{l}\text { Pair } 15 \text { Larsen and Tubro Ltd. Post and Pre } \\
\text {-Merger }\end{array}$ & -3.2333 & 3.3176 & 1.3544 & -6.7149 & .24832 & -2.387 & 5 & 0.063 \\
\hline Pair 16 MphasisLtd.Post and Pre-Merger & -11.2583 & 4.5264 & 1.8479 & -16.0085 & -6.5081 & -6.093 & 5 & 0.002 \\
\hline $\begin{array}{l}\text { Pair } 17 \text { Punjab Chemicals \& Crop Protection Ltd. } \\
\text { Post and } \\
\text { Pre-Merger }\end{array}$ & 8.6500 & 14.3231 & 5.8474 & -6.3812 & 23.6812 & 1.479 & 5 & 0.199 \\
\hline Pair 18 R S W MLtd. Post and Pre -Merger & 1.2333 & 3.2850 & 1.3411 & -2.2141 & 4.6807 & 0.920 & 5 & 0.400 \\
\hline $\begin{array}{l}\text { Pair } 19 \text { Tata Global Beverages Ltd. Post and Pre } \\
\text {-Merger }\end{array}$ & -0.6816 & 2.5990 & 1.0610 & -3.4091 & 2.0458 & -0.642 & 5 & 0.549 \\
\hline Pair 20 Thermax Ltd. Post and Pre - Merger & -4.2916 & 5.5629 & 2.2710 & -10.1296 & 1.5463 & -1.890 & 5 & 0.117 \\
\hline
\end{tabular}




\begin{tabular}{|ll|c|c|c|c|c|c|c|}
\hline & & & & & & \\
\hline $\begin{array}{l}\text { Pair 21 Universal Cables Ltd. Post and Pre - } \\
\text { Merger }\end{array}$ & -4.3816 & 4.8535 & 1.9814 & -9.4751 & 0.7117 & -2.211 & 5 & 0.078 \\
\hline $\begin{array}{l}\text { Pair 22 VI P Industries Ltd. Post and Pre - } \\
\text { Merger }\end{array}$ & $\mathbf{- 5 . 8 2 8 3}$ & $\mathbf{5 . 2 6 3 4}$ & $\mathbf{2 . 1 4 8 7}$ & $\mathbf{- 1 1 . 3 5 1 9}$ & $\mathbf{- 0 . 3 0 4 7}$ & $\mathbf{- 2 . 7 1 2}$ & $\mathbf{5}$ & $\mathbf{0 . 0 4 2}$ \\
\hline $\begin{array}{l}\text { Pair 23 Videocon Industries Ltd. Post and Pre - } \\
\text { Merger }\end{array}$ & -0.6966 & 2.4588 & 1.0038 & -3.2771 & 1.8837 & -0.694 & 5 & 0.519 \\
\hline Pair 24 Wanbury Ltd. Post and Pre - Merger & 0.5650 & 8.1934 & 3.3449 & -8.0335 & 9.1635 & 0.169 & 5 & 0.872 \\
\hline
\end{tabular}

Table 5: Paired Sample Test Results for Net Profit Margin Ratio of Acquiring Firms

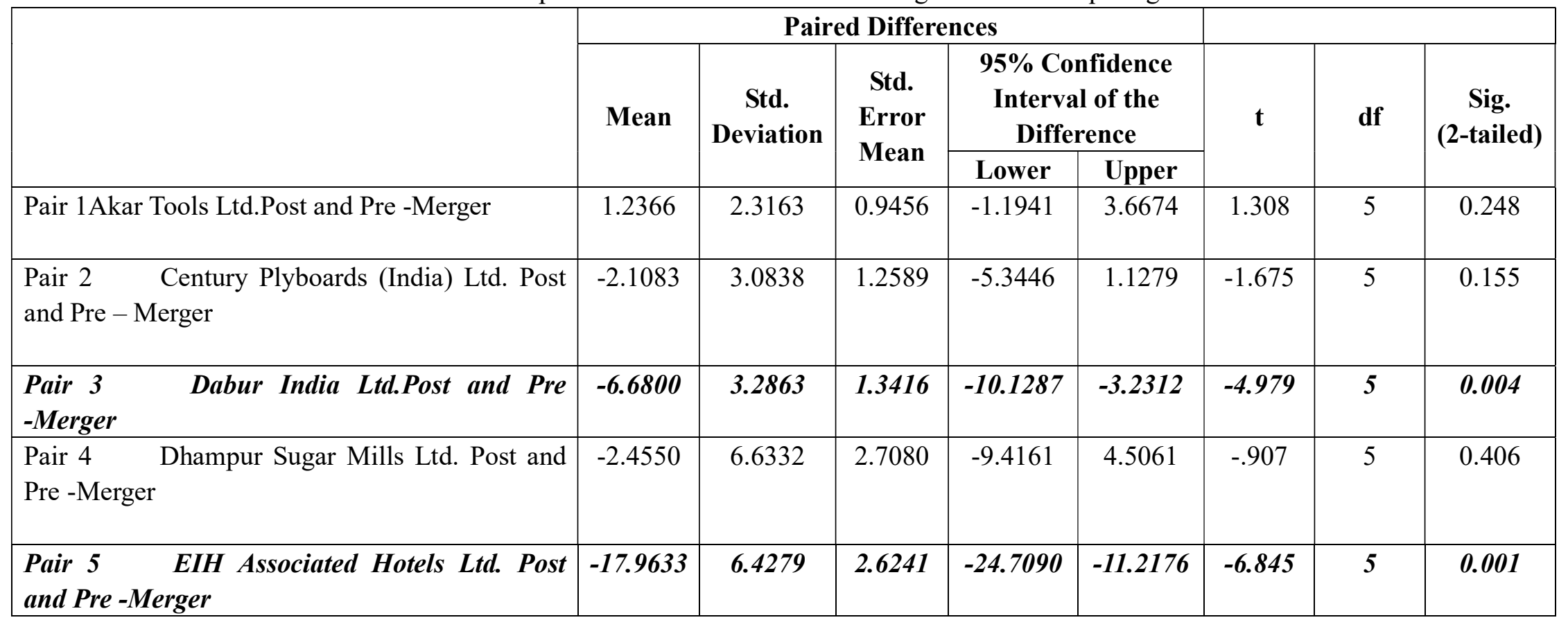




\begin{tabular}{|c|c|c|c|c|c|c|c|c|}
\hline $\begin{array}{llll}\text { Pair } 6 & \text { Forbes\&Co.Ltd. Post and Pre } \\
\text {-Merger } & \end{array}$ & 8.9183 & 9.2298 & 3.7680 & -0.76776 & 18.6044 & 2.367 & 5 & 0.064 \\
\hline $\begin{array}{lll}\text { Pair } 7 & \text { Goa Carbon Ltd. Post and Pre } \\
\text {-Merger } & \end{array}$ & 0.7583 & 4.1132 & 1.6792 & -3.5582 & 5.0748 & 0.452 & 5 & 0.670 \\
\hline H I L Ltd. Post and Pre-Merger & -7.1966 & 3.0097 & 1.2287 & -10.3552 & -4.0381 & -5.857 & 5 & 0.002 \\
\hline H M T Ltd. Post and Pre -Merger & 18.5033 & 41.9974 & 17.1453 & -25.5703 & 62.5769 & 1.079 & 5 & 0.330 \\
\hline $\begin{array}{l}\text { Pair } 10 \text { Hindustan Unilever Ltd. Post and Pre } \\
\text {-Merger }\end{array}$ & 0.9050 & 3.6032 & 1.4710 & -2.8764 & 4.6864 & 0.615 & 5 & 0.565 \\
\hline Pair 11J S W Steel Ltd. Post and Pre -Merger & -12.8483 & 17.7202 & 7.2342 & -31.4446 & 5.7479 & -1.776 & 5 & 0.136 \\
\hline $\begin{array}{l}\text { Pair } 12 \text { Kamat Hotels (India)Ltd.Post and Pre } \\
\text {-Merger }\end{array}$ & -3.2733 & 7.2213 & 2.9481 & -10.8516 & 4.3050 & -1.110 & 5 & 0.317 \\
\hline $\begin{array}{l}\text { Pair } 13 \text { Kesoram Industries Ltd. Post and Pre } \\
\text {-Merger }\end{array}$ & -1.4500 & 7.4202 & 3.0292 & -9.2370 & 6.3370 & -0.479 & 5 & 0.652 \\
\hline $\begin{array}{l}\text { Pair } 14 \text { Lakshmi Machine Works Ltd.Post and } \\
\text { Pre-Merger }\end{array}$ & -3.3600 & 1.6678 & 0.6809 & -5.1103 & -1.6096 & -4.935 & 5 & 0.004 \\
\hline $\begin{array}{l}\text { Pair } 15 \text { Larsen and Tubro Ltd. Post and Pre } \\
\text {-Merger }\end{array}$ & -4.1316 & 2.0596 & 0.8408 & -6.2931 & -1.9702 & -4.914 & 5 & 0.004 \\
\hline
\end{tabular}




\begin{tabular}{|c|c|c|c|c|c|c|c|c|}
\hline Pair 16MphasisLtd.Post and Pre -Merger & 1.59167 & 8.25078 & 3.36837 & -7.06700 & 10.25033 & 0.473 & 5 & 0.656 \\
\hline $\begin{array}{l}\text { Pair } 17 \text { Punjab Chemicals \& Crop Protection } \\
\text { Ltd.Post and } \\
\text { Pre-Merger }\end{array}$ & 10.1050 & 15.8777 & 6.4820 & -6.5577 & 26.7677 & 1.559 & 5 & 0.180 \\
\hline Pair 18 R S W M Ltd. Post and Pre -Merger & 0.9700 & 3.3040 & 1.3488 & -2.4974 & 4.4374 & 0.719 & 5 & 0.504 \\
\hline $\begin{array}{l}\text { Pair } 19 \text { Tata Global Beverages Ltd. Post and } \\
\text { Pre -Merger }\end{array}$ & -7.6050 & 7.9929 & 3.2631 & -15.9930 & 0.7830 & -2.331 & 5 & 0.067 \\
\hline Pair 20 Thermax Ltd. Post and Pre - Merger & -1.9550 & 5.3339 & 2.1775 & -7.5525 & 3.6425 & -0.898 & 5 & 0.410 \\
\hline $\begin{array}{l}\text { Pair } 21 \text { Universal Cables Ltd. Post and Pre - } \\
\text { Merger }\end{array}$ & -3.7033 & 3.9941 & 1.6306 & -7.8949 & 0.4882 & -2.271 & 5 & 0.072 \\
\hline $\begin{array}{l}\text { Pair } 22 \text { V I P Industries Ltd. Post and Pre - } \\
\text { Merger }\end{array}$ & -3.3600 & 3.2365 & 1.3213 & -6.7565 & 0.0365 & -2.543 & 5 & 0.052 \\
\hline $\begin{array}{l}\text { Pair } 23 \text { Videocon Industries Ltd. Post and Pre - } \\
\text { Merger }\end{array}$ & -1.9950 & 3.2738 & 1.3365 & -5.4307 & 1.4407 & -1.493 & 5 & 0.196 \\
\hline Pair 24 Wanbury Ltd. Post and Pre - Merger & 2.0166 & 15.9993 & 6.5317 & -14.7736 & 18.8069 & 0.309 & 5 & 0.770 \\
\hline
\end{tabular}

Table 6: Paired Sample Test Results for Asset Turnover Ratio of Acquiring Firms

\begin{tabular}{|c|c|c|c|c|c|c|c|c|}
\hline & \multicolumn{5}{|c|}{ Paired Differences } & \multirow{3}{*}{$\mathbf{t}$} & \multirow{3}{*}{ df } & \multirow{3}{*}{$\begin{array}{c}\text { Sig. } \\
\text { (2-tailed) }\end{array}$} \\
\hline & \multirow[t]{2}{*}{ Mean } & \multirow[t]{2}{*}{$\begin{array}{c}\text { Std. } \\
\text { Deviation }\end{array}$} & \multirow[t]{2}{*}{$\begin{array}{l}\text { Std. } \\
\text { Error } \\
\text { Mean }\end{array}$} & \multicolumn{2}{|c|}{$\begin{array}{c}\text { 95\% Confidence } \\
\text { Interval of the } \\
\text { Difference } \\
\end{array}$} & & & \\
\hline & & & & Lower & Upper & & & \\
\hline Pair 1Akar Tools Ltd.Post and Pre-Merger & -0.2350 & 0.0728 & 0.0297 & -0.3114 & -0.1585 & -7.899 & 5 & 0.001 \\
\hline
\end{tabular}




\begin{tabular}{|c|c|c|c|c|c|c|c|c|}
\hline $\begin{array}{l}\text { Pair } 2 \quad \text { Century Plyboards (India) Ltd. Post and } \\
\text { Pre - Merger }\end{array}$ & 0.1000 & 0.1739 & 0.0709 & -0.0824 & 0.2824 & 1.409 & 5 & 0.218 \\
\hline Dabur India Ltd.PostandPre -Merger & 0.0666 & 0.4638 & 0.1893 & -0.4200 & 0.5533 & 0.352 & 5 & 0.739 \\
\hline $\begin{array}{ll}\text { Pair } 4 & \text { Dhampur Sugar Mills Ltd. Post and Pre } \\
\text {-Merger } & \end{array}$ & 0.0950 & 0.4271 & 0.1743 & -0.3532 & 0.5432 & 0.545 & 5 & 0.609 \\
\hline $\begin{array}{l}\text { Pair } 5 \quad \text { EIH Associated Hotels Ltd. Post and } \\
\text { Pre-Merger }\end{array}$ & -0.1483 & 0.0256 & 0.0104 & -0.1752 & -0.1214 & -14.179 & 5 & 0.000 \\
\hline $\begin{array}{lllll}\text { Pair } 6 & \text { Forbesd Co. Ltd. Post and Pre } \\
\text {-Merger }\end{array}$ & 0.2400 & 0.0779 & 0.0318 & 0.1581 & 0.3218 & 7.539 & 5 & 0.001 \\
\hline Goa Carbon Ltd. Post and Pre -Merger & -0.2466 & 0.3454 & 0.1410 & -0.6092 & 0.1158 & -1.749 & 5 & 0.141 \\
\hline H I L Ltd. Post and Pre-Merger & -0.4466 & 0.2515 & 0.1026 & -0.7106 & -0.1827 & -4.350 & 5 & 0.007 \\
\hline H M T Ltd. Post and Pre -Merger & 0.1900 & 0.2132 & 0.0870 & -0.0338 & 0.4138 & 2.182 & 5 & 0.081 \\
\hline $\begin{array}{l}\text { Pair } 10 \text { Hindustan Unilever Ltd. Post and Pre } \\
\text {-Merger }\end{array}$ & -0.3766 & 0.4224 & 0.1724 & -0.8199 & 0.0666 & -2.184 & 5 & 0.081 \\
\hline Pair 11J S W Steel Ltd. Post and Pre-Merger & -0.2583 & 0.2421 & 0.0988 & -0.5124 & -0.0042 & -2.614 & 5 & 0.047 \\
\hline $\begin{array}{ll}\text { Pair } 12 & \text { Kamat Hotels (India)Ltd.Post and Pre } \\
\text {-Merger } & \end{array}$ & 0.0416 & 0.0462 & 0.0188 & -0.0068 & 0.0901 & 2.208 & 5 & 0.078 \\
\hline
\end{tabular}




\begin{tabular}{|c|c|c|c|c|c|c|c|c|}
\hline $\begin{array}{l}\text { Pair } 13 \text { Kesoram Industries Ltd. Post and Pre } \\
\text {-Merger }\end{array}$ & 0.1916 & 0.3796 & 0.1549 & -0.2067 & 0.5900 & 1.237 & 5 & 0.271 \\
\hline $\begin{array}{l}\text { Pair } 14 \text { Lakshmi Machine Works Ltd.Postand Pre } \\
\text {-Merger }\end{array}$ & -0.0466 & 0.3948 & 0.1612 & -0.4610 & 0.3677 & -0.290 & 5 & 0.784 \\
\hline $\begin{array}{l}\text { Pair } 15 \text { Larsen and Tubro Ltd. Post and Pre } \\
\text {-Merger }\end{array}$ & 0.0116 & 0.3042 & 0.1241 & -0.3075 & 0.3309 & 0.094 & 5 & 0.929 \\
\hline Pair 16MphasisLtd.Postand Pre -Merger & -0.4400 & 0.5309 & 0.2167 & -0.9972 & 0.1172 & -2.030 & 5 & 0.098 \\
\hline $\begin{array}{l}\text { Pair } 17 \text { Punjab Chemicals \& Crop Protection } \\
\text { Ltd.Post and } \\
\text { Pre-Merger }\end{array}$ & 0.4400 & 0.3391 & 0.1384 & 0.0841 & 0.7958 & 3.178 & 5 & 0.025 \\
\hline Pair $18 \quad R S W M$ Ltd. Post and Pre-Merger & 0.1600 & 0.1190 & 0.0485 & 0.0351 & 0.2848 & 3.294 & 5 & 0.022 \\
\hline $\begin{array}{l}\text { Pair } 19 \text { Tata Global Beverages Ltd. Post and Pre } \\
\text {-Merger }\end{array}$ & 0.1733 & 0.0995 & 0.0406 & 0.0688 & 0.2777 & 4.266 & 5 & 0.008 \\
\hline Pair 20 Thermax Ltd. Post and Pre - Merger & -0.3383 & 0.1792 & 0.0731 & -0.5264 & -0.1502 & -4.623 & 5 & 0.006 \\
\hline $\begin{array}{l}\text { Pair } 21 \text { Universal Cables Ltd. Post and Pre - } \\
\text { Merger }\end{array}$ & -0.3200 & 0.1099 & 0.0448 & -0.4353 & -0.2046 & -7.132 & 5 & 0.001 \\
\hline $\begin{array}{l}\text { Pair } 22 \text { V I P Industries Ltd. Post and Pre - } \\
\text { Merger }\end{array}$ & -0.2200 & 0.0789 & 0.0322 & -0.3029 & -0.1371 & -6.822 & 5 & 0.001 \\
\hline $\begin{array}{l}\text { Pair } 23 \text { Videocon Industries Ltd. Post and Pre - } \\
\text { Merger }\end{array}$ & 0.1583 & 0.1758 & 0.0718 & -0.0262 & 0.3429 & 2.205 & 5 & 0.079 \\
\hline Pair 24 Wanbury Ltd. Post and Pre - Merger & 0.1233 & 0.2118 & 0.0864 & -0.0989 & 0.34562 & 1.426 & 5 & 0.213 \\
\hline
\end{tabular}




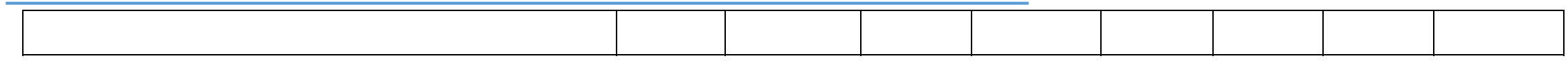

Table 7: Forecasted Value of All Ratios based on ARIMA Model

\begin{tabular}{|c|c|c|c|c|c|c|}
\hline \multirow{2}{*}{ Companies Name } & \multicolumn{2}{|c|}{ Return on Assets (\%) } & \multicolumn{2}{|c|}{ Net Profit Margin (\%) } & \multicolumn{2}{|c|}{ Asset Turnover Ratio (Times) } \\
\hline & 2016 & 2017 & 2016 & 2017 & 2016 & 2017 \\
\hline Akar Tools Ltd. & 0.62 & 0.10 & 0.30 & -0.13 & 1.67 & 1.77 \\
\hline Century Plyboards (India) Ltd. & 16.83 & 19.67 & 10.06 & 11.42 & 1.69 & 1.76 \\
\hline Dabur India Ltd. & 18.10 & 19.47 & 13.91 & 14.14 & 1.29 & 1.36 \\
\hline Dhampur Sugar Mills Ltd. & -1.89 & -3.90 & -3.73 & -7.90 & 0.48 & 0.29 \\
\hline EIH Associated Hotels Ltd. & 7.44 & 8.94 & 12.62 & 14.84 & 0.62 & 0.67 \\
\hline Forbes \& Co. Ltd. & 1.46 & 3.43 & 3.17 & 7.32 & 0.71 & 0.82 \\
\hline Goa Carbon Ltd. & -7.99 & -12.74 & -8.71 & -13.45 & 0.59 & 0.28 \\
\hline H I L Ltd. & 6.17 & 4.27 & 4.51 & 3.41 & 1.41 & 1.38 \\
\hline H M T Ltd. & -6.45 & -6.11 & -188.97 & -238.00 & 0.02 & -0.01 \\
\hline
\end{tabular}




\begin{tabular}{|c|c|c|c|c|c|c|}
\hline Hindustan Unilever Ltd. & 32.46 & 34.13 & 14.10 & 15.22 & 2.33 & 2.29 \\
\hline J S W Steel Ltd. & 3.47 & 4.48 & 4.86 & 5.80 & 0.67 & 0.70 \\
\hline Kamat Hotels (India) Ltd. & 3.47 & 4.48 & 4.86 & 5.80 & 0.67 & 0.70 \\
\hline Kesoram Industries Ltd. & -5.34 & -4.77 & -7.81 & -8.39 & 0.81 & 0.85 \\
\hline Lakshmi Machine Works Ltd. & 11.23 & 13.39 & 8.48 & 9.54 & 1.34 & 1.45 \\
\hline Larsen and Tubro Ltd. & 4.82 & 3.89 & 8.01 & 7.01 & 0.63 & 0.62 \\
\hline MphasisLtd. & 6.25 & 1.10 & 15.55 & 11.98 & 0.48 & 0.39 \\
\hline $\begin{array}{l}\text { Punjab Chemicals } \quad \& \quad \text { Crop } \\
\text { Protection Ltd. }\end{array}$ & 5.76 & 11.92 & 7.40 & 15.45 & 1.02 & 1.19 \\
\hline R S W M Ltd. & 5.39 & 7.15 & 4.20 & 6.05 & 1.50 & 1.54 \\
\hline Tata Global Beverages Ltd. & 6.53 & 7.36 & 10.50 & 11.08 & 0.62 & 0.69 \\
\hline Thermax Ltd. & 6.10 & 5.62 & 6.75 & 6.87 & 0.92 & 0.86 \\
\hline Universal Cables Ltd. & -6.92 & -8.54 & -6.03 & -7.52 & 1.10 & 1.04 \\
\hline
\end{tabular}




\begin{tabular}{|l|c|c|c|c|c|c|}
\hline V I P Industries Ltd. & 8.45 & 6.91 & 3.37 & 1.94 & 2.29 & 2.46 \\
\hline Videocon Industries Ltd. & 0.02 & 0.23 & -0.44 & -0.073 & 0.53 & 0.55 \\
\hline Wanbury Ltd. & -88.85 & -115.62 & -50.17 & -61.13 & 2.04 & 2.50 \\
\hline
\end{tabular}


